\title{
Perancangan Pengukuran Kinerja di PT Sayuran Siap Saji dengan Pendekatan Balanced Scorecard
}

\author{
Designing a Performance Measurement at PT Sayuran Siap Saji \\ using Balanced Scorecard Approach \\ Yuni Astuti Tri Tartiani ${ }^{* 1}$, Ujang Sumarwan ${ }^{2 \sharp}$, dan Sahara ${ }^{3 \#}$ \\ ${ }^{1}$ Magister Manajemen dan Bisnis, Sekolah Bisnis Institut Pertanian Bogor \\ 2 Departemen Ilmu Keluarga dan Konsumen, Fakultas Ekologi Manusia, Institut Pertanian Bogor \\ ${ }^{3}$ Departemen Ekonomi, Fakultas Ekonomi dan Manajemen, Institut Pertanian Bogor \\ \# Jl. Kamper Kampus IPB Darmaga, Bogor 16880
}

\begin{abstract}
ABSTRAK
PT Sayuran Siap Saji merupakan salah satu perusahaan pemasok sayuran fresh cut yang sedang berkembang. Dalam mempertahankan eksistensi sebagai dampak dari persaingan bisnis yang semakin ketat, PT Sayuran Siap Saji perlu terus memperbaiki kinerjanya. Tujuan penelitian untuk merancang pengukuran kinerja di PT Sayuran Siap Saji dengan menggunakan pendekatan Balanced Scorecard (BSC). BSC adalah alat manajemen pengukur kinerja secara komprehensif. Penelitian ini dilakukan menggunakan teknik deskriptif dalam bentuk studi kasus. Penetapan narasumber dilakukan dengan metode purposive sampling yaitu lima pakar dari pihak manajemen PT Sayuran Siap Saji. Data dikumpulkan melalui teknik wawancara mendalam menggunakan alat bantu kuesioner dan studi pustaka. Terdapat empat perspektif yang menjadi peubah dalam penelitian ini, yaitu perspektif keuangan, perspektif pelanggan, perspektif proses bisnis internal dan perspektif pertumbuhan dan pembelajaran. Analytic Hierarchy Process (AHP) digunakan untuk menentukan prioritas perspektif dan sasaran strategik BSC. Hasil menunjukkan perspektif pelanggan terdapat empat sasaran strategik yang teridentifikasi dan masing-masing lima sasaran strategik pada perspektif keuangan, perspektif proses bisnis internal dan perspektif pertumbuhan dan pembelajaran. Pada perspektif pelanggan, peningkatan kepuasan dan kepercayaan dari pelanggan menunjukkan kontribusi tertinggi, sedangkan perspektif keuangan, memenuhi persyaratan kepada pemasok dengan kontribusi tertinggi. Pada perspektif pertumbuhan dan pembelajaran, peningkatan kemampuan dan pengembangan sumber daya manusia menunjukkan kontribusi tertinggi, dan pada perspektif proses bisnis internal, produk dan proses produksi sesuai dengan standar menunjukkan kontribusi tertinggi terhadap kinerja perusahaan. Artinya keempat sasaran strategik dari masing-masing prespektif yang memiliki kontribusi tertinggi tersebut menjadi dasar dalam penentuan target dan inisiatif strategik yang lebih baik bagi perusahaan dalam mempertahankan dan meningkatkan kinerjanya.
\end{abstract}

Kata kunci: analytic hierarchy process, balanced scorecard, sayuran siap saji

\section{ABSTRACT}

PT Sayuran Siap Saji is one of the fresh cut vegetable supplier companies that are developing. In maintaining existence as a result of increasingly fierce business competition, PT X needs to continue to improve its performance. The objectives of the research were to built performance measurement at PT Sayuran Siap Saji using Balanced Scorecard (BSC). BSC is a management tool in measuring performance comprehensively. This research used descriptive techniques through case studies. Determination of resource persons is done by purposive sampling method, namely five experts from the management of PT Sayuran Siap Saji. The data was collected through in-depth interview techniques, structured interviews using questionnaires and literature study. There were four perspectives that became variables in this research, which were financial perspective, customer perspective, internal business process perspective and growth and learning perspective. Analytic Hierarchy Process (AHP) was used to determined the

\footnotetext{
*) Korespondensi:

Magister Manajemen dan Bisnis, Sekolah Bisnis Institut Pertanian Bogor 16151; email: yuni.tartiani@gmail.com
} 
perspective priority and strategic objectives of Balanced Scorecard. The result showed that in the customer perspective, four strategic objectives were identified and five strategic objectives for each of financial perspectives, internal business process perspectives and learning and growth perspectives were identified. In the customer perspective, enhancement of satisfaction and trust from customers shows the highest contribution, meanwhile in the financial perspective, fulfill the requirements to the supplier shows the highest contribution. In the growth and learning perspective, enhancement of the capabilities and the development of the human resources shows the highest contribution, and in the internal business process perspective, product and production process in accordance with the standards shows the highest contribution to the companies performance. This means that the four strategic objectives of each perspective that have the highest contribution are the basis for determining targets and better strategic initiatives for companies in maintaining and improving their performance.

Key words: analytic hierarchy process, balanced scorecard, fresh cut vegetable

\section{PENDAHULUAN}

Peningkatan dan perbaikan kinerja sangat penting dilakukan agar perusahaan dapat mempertahankan eksistensinya di tengah persaingan bisnis yang semakin ketat. Perancangan suatu sistem pengukuran kinerja yang komprehensif merupakan dasar perencanaan strategi perusahaan agar lebih baik lagi kedepannya. Pengukuran yang hanya berdasarkan pada laporan keuangan tidak lagi memadai untuk menghadapi lingkungan bisnis yang semakin kompleks. Ukuran-ukuran finansial belum dapat memberikan indikatorindikator yang dapat dipercaya untuk menilai kinerja perusahaan saat ini, khususnya memberikan ekspektasi bagi pemegang saham (Sumarwan et al. 2009). Setiap perusahaan dapat menggunakan berbagai pendekatan dalam mengukur kinerjanya, salah satu pengukuran kinerja komprehensif dan memberikan suatu pandangan lebih seimbang dibandingkan metode lainnya adalah Balanced Scorecard (Johnson, 2007).

BSC adalah salah satu model sistem pengukuran kinerja dengan strategi sebagai titik awal menerjemahkan ke dalam ukuran kinerjanya (Kaplan dan Norton, 1996). Dalam BSC, setiap perspektif, sasaran strategik dan Key Performance Indicator (KPI) perlu dilakukan pembobotan untuk melihat kontribusinya terhadap kinerja perusahaan secara keseluruhan (Suryani et al. 2014). Salah satu metode yang dapat digunakan adalah Analytic Hierarchy Process (AHP). Persoalan kompleks dapat disederhanakan dan dipercepat proses pengambilan keputusannya dengan AHP (Marimin dan Magfiroh, 2010). AHP adalah metode handal dan mudah digunakan untuk pengambilan keputusan. Itulah mengapa AHP menjadi metode yang paling sering digunakan dan sangat populer diantara para ahli dan praktisi (Jovanovic dan Krivokapic,
2008). Penggunaan BSC menjadikan organisasi menerima banyak manfaat (Sharma dan Bhagwat, 2007), dan masalah baru seperti bias serta informasi yang overload dapat dipecahkan dengan penggunaan AHP (Ching dan Chan, 2006). PT Sayuran Siap Saji merupakan salah satu perusahaan pemasok sayuran yang sedang berkembang. Perancangan pengukuran kinerja komprehensif dengan pendekatan BSC dapat membantu PT Sayuran Siap Saji dalam mencapai tujuannya, serta memperbaiki dan meningkatkan kinerjanya.

Sejalan dengan peningkatan pendapatan masyarakat, menyebabkan tren konsumsi pangan menurun, namun untuk tren high value agriculture semakin meningkat, sebagaimana dinyatakan dalam teori ekonomi Bennett's law dan pernyataan United States Department of Agriculture Economic Research Service (USDAERS). Perubahan gaya hidup masyarakat perkotaan juga menyebabkan opportunity cost terhadap memasak sendiri menjadi tinggi, sehingga pembelian terhadap makanan siap saji meningkat. Peningkatan konsumsi makanan sehat termasuk di dalamnya adalah sayuran dan pola hidup masyarakat yang menyukai kepraktisan ini direspon oleh PT Sayuran Siap Saji yang merupakan pemasok sayuran fresh cut. Sebagai dampak dari persaingan yang semakin ketat, bisnis yang dilakukan PT Sayuran Siap Saji pernah mengalami penurunan. Sebagai upaya mempertahankan eksistensi perusahaan, maka PT Sayuran Siap Saji perlu memperbaiki dan meningkatkan kinerjanya melalui evaluasi pengukuran kinerja komprehensif dengan pendekatan BSC.

Tujuan penelitian ini adalah merancang suatu pengukuran kinerja dengan pendekatan BSC bagi PT Sayuran Siap Saji dengan terlebih dahulu menganalisis sasaran strategik dan KPI, menentukan target dan inisiatif strategik, menentukan prioritas sasaran strategik dalam empat perspektif 
BSC, serta menyusun peta strategi berdasarkan sasaran strategik pada setiap perspektif BSC.

Beberapa penelitian sebelumnya telah banyak membahas mengenai pengukuran kinerja di beberapa lembaga atau perusahaan, baik profit maupun nirlaba. Perancangan BSC pada lembaga profit beberapa diantaranya telah dilakukan oleh Wang (2012), Hanuma \& Kiswara (2011), Meena \& Thakkar (2014), Wang, Zhang \& Zeng (2012). Perancangan BSC pada lembaga nirlaba telah dilakukan oleh Pietrzak, Paliszkiewicz \& Klepacki (2015) dan Suhendi (2012). Penelitian terkait pengukuran kinerja dengan BSC dan pembobotan dengan AHP juga telah dilakukan oleh Fakharian, Danaei \& Hematian (2014), Rauf (2012), Chu, Wang \& Dai (2009) dan Erbasi \& Parlakkaya (2012).

PT Sayuran Siap Saji merupakan perusahaan berorientasi profit dan bergerak di bidang agribisnis, yaitu memasok sayuran fresh cut dan merupakan perusahaan yang baru berkembang. Penelitian terkait BSC di perusahaan agribisnis, beberapa diantaranya dilakukan oleh Paustian, Welner \& Theuvsen (2015), Hidayati (2012), Rosmiati, Mustafid \& Widiyanto (2015) dan Callado \& Jack (2015), namun masih sedikit penelitian terkait perancangan awal BSC di perusahaan agribisnis dengan indikator terkait pertanian di perusahaan pemasok sayuran yang baru berkembang.

Penelitian ini menjadi penting dilakukan sejalan dengan penelitian Lokatili dan Devie (2013) yang menunjukkan hubungan nyata dan positif penggunaan BSC terhadap keunggulan bersaing dan kinerja perusahaan. Pengaruh penggunaan BSC tertinggi terhadap kinerja perusahaan. Saat ini pengukuran kinerja yang dilakukan di PT Sayuran Siap Saji masih berfokus pada laporan keuangan, maka diperlukan perencanaan strategik (renstra) berdasarkan pengukuran kinerja yang komprehensif seperti pada pendekatan BSC.

Penelitian ini diawali dengan menerjemahkan visi misi dan tujuan PT Sayuran Siap Saji, serta melakukan wawancara dengan pihak-pihak yang dianggap kompeten di bidangnya, yaitu pihak manajemen PT Sayuran Siap Saji. Dari hasil tersebut didapatkan sasaran strategik, KPI sebagai target dan inisiatif strategik dari empat perspektif pengukuran kinerja dengan BSC, yaitu perspektif keuangan, perspektif pelanggan, perspektif pertumbuhan dan pembelajaran, serta perspektif proses bisnis internal. Metode AHP dimaksudkan untuk menganalisis perspektif yang menjadi prioritas perusahaan. Selanjutnya dilakukan pemetaan terhadap srategi yang telah ditentukan ukurannya sebagai dasar renstra PT Sayuran Siap Saji kedepannya.

\section{METODE PENELITIAN}

Penelitian menggunakan teknik deskrtiptif dalam bentuk studi kasus. Teknik penetapan narasumber dilakukan dengan metode purposive sampling, dimana manajemen PT Sayuran Siap Saji dengan pertimbangan kompetensi dan kapabilitas masing-masing bidangnya, sehingga merupakan narasumber expert (pakar). Penelitian dilakukan di PT Sayuran Siap Saji yang berlokasi di Megamendung Bogor, Jawa Barat, dengan waktu penelitian dilaksanakan pada bulan Juli sampai dengan bulan Oktober 2016. Teknik pengumpulan data penelitian dilakukan dengan cara Indepth Interview, Wawancara Terstruktur menggunakan alat bantu kuesioner, dan studi pustaka.

Teknik pengolahan dan analisis data yang digunakan adalah analisis BSC dan AHP. Prinsip BSC dijadikan dasar dalam menentukan sasaran strategik serta KPI menetapkan target dan inisiatif strategik dalam mencapai sasaran strategik. Hal ini sejalan dengan penelitian Suswono (2010), yaitu penggunaan AHP memungkinkan diketahuinya sasaran strategik yang menjadi prioritas dalam upaya perbaikan kinerja. Skala pengukuran yang digunakan adalah skala 1-9 (Saaty, 2001). Pengolahan data menggunakan software expert choice 2000 .

Empat perspektif BSC yang menjadi peubah dalam penelitian ini adalah:

1. Kinerja Perspektif Keuangan, Ukuran kinerja ini memberikan petunjuk apakah strategi perusahaan, implementasi dan pelaksanaannya memberikan kontribusi atau tidak terhadap peningkatan pendapatan perusahaan.

2. Kinerja Perspektif Pelanggan, Ukuran kinerja ini untuk mengetahui bagaimana pelanggan PT Sayuran Siap Saji dalam hal ini adalah restoran dan convenience store serta masyara-kat menilai produk atau jasa serta perusahaan secara keseluruhan sehingga informasi mengenai pelanggan dapat digunakan untuk menentukan strategi selanjutnya.

3. Kinerja Perspektif Proses Bisnis Internal, PT Sayuran Siap Saji dalam hal ini perlu mengidentifikasi proses-proses paling kritis untuk mencapai tujuan dalam memberikan pelayanan yang terbaik dan produk yang berkualitas. 
4. Kinerja Perspektif Pertumbuhan dan Pembelajaran, Ukuran kinerja ini berhubungan dengan pengembangan sumber daya manusia agar semakin kompeten serta pembelajaran lainnya yang dapat menghasilkan kinerja yang tinggi bagi perusahaan.

\section{HASIL DAN PEMBAHASAN}

Sasaran strategik merupakan penjabaran dari visi, misi dan tujuan PT Sayuran Siap Saji yang lebih spesifik dan realistik. Sasaran strategik dan KPI PT Sayuran Siap Saji sesuai perspektif BSC adalah:

Perspektif keuangan, meliputi sasaran strategik peningkatan laba dengan KPI tingkat pertumbuhan volume penjualan, net profit margin (NPM), pertumbuhan pendapatan, return on investment (ROI) dan total aset turnover. Sasaran strategik meminimalkan struktur biaya dengan KPI persentase harga pokok penjualan terhadap penjualan bersih dan operating ratio. Sasaran strategik mampu memenuhi kewajiban terhadap pemasok dengan KPI day of payable dan tingkat hutang, serta sasaran strategik pengendalian risiko dengan KPI rataan umur piutang, tingkat persediaan dan rasio dana sendiri terhadap pinjaman.

Perspektif pelanggan, meliputi sasaran strategik peningkatan kepuasan dan kepercayaan pelanggan dengan KPI persentase jumlah keluhan, persentase retur dan persentase pelanggan hilang. Sasaran strategik peningkatan citra dan performa perusahaan dengan KPI persentase pelanggan baru. Sasaran strategik peningkatan pesanan dipenuhi dengan KPI jumlah pesanan yang dipenuhi. Sasaran strategik menjadi pemain dominan pada industri fresh cut dengan KPI persentase market share, serta sasaran strategik meningkatkan hubungan baik kepada pelanggan dengan KPI terkait jumlah kunjungan rutin, frekuensi support pelanggan dan harga produk kompetitif.

Perspektif proses bisnis internal, terdiri dari sasaran strategik produk dan proses produksi sesuai standar dengan KPI jumlah sertifikasi dan standardisasi, serta persentase product losses. Sasaran strategik distribusi yang efisien dengan KPI cost distribusi dan tingkat waktu tempuh distribusi. Sasaran strategik peningkatan kerjasama penelitian dengan KPI jumlah kerjasama penelitian. Sasaran pelaporan terintegrasi dan tepat waktu dengan KPI persentase laporan unit kerja yang tepat waktu, akurat dan accountable.
Sasaran strategik hubungan pemasok dengan KPI turnover mitra tani, perbandingan jumlah mitra tani dan mitra beli, persentase pengiriman bahan baku yang tepat waktu, tepat mutu dan tepat jumlah, total pengeluaran pinjaman benih untuk mitra tani dan total pengeluaran pinjaman alat produksi dan pendanaan untuk mitra tani.

Perspektif pertumbuhan dan pembelajaran, meliputi sasaran strategik peningkatan inovasi dan pembelajaran dengan KPI jumlah jenis inovasi sayuran fresh cut baru yang dihasilkan per periode dan persentase saran yang diimplementasikan. Sasaran strategik Peningkatan komitmen karyawan dengan KPI persentase tingkat keterlambatan, tingkat kehadiran karyawan dan turnover karyawan. Sasaran strategik peningkatan kapabilitas dan pengembangan SDM dengan KPI Jumlah pelatihan karyawan, frekuensi konsultasi dengan tenaga penyuluh, persentase training cost, performance appraisal, dan indeks kependidikan karyawan. Sasaran strategik mutu teknologi informasi yang digunakan dengan KPI frekuensi kerusakan sistem aplikasi komputer dan frekuensi gangguan jaringan, serta sasaran strategik penghargaan pada SDM dengan KPI persentase pegawai yang memperoleh reward dan persentase penugasan yang memiliki payung hukum atau SOP yang jelas, serta memenuhi kaidah keselamatan dan kesehatan kerja (K3). KPI pada setiap sasaran strategik memiliki target dan inisiatif strategik yang ditentukan berdasarkan diskusi dengan narasumber dan berdasarkan pada Rencana Kerja dan Anggaran Perusahaan (RKAP).

\section{Pembobotan Perspektif, Sasaran Strategik dan KPI Menggunakan AHP}

Pembobotan dan penentuan prioritas perspektif dan sasaran strategik berdasarkan empat perspektif BSC dilakukan dengan metode AHP. Hasil pembobotan setiap perspektif BSC dapat dilihat pada Gambar 1, Perspektif pelanggan memberikan kontribusi tertinggi dalam peningkatan kinerja PT Sayuran Siap Saji, yaitu 0,515. Hal ini sejalan dengan penelitian Sharma dan Bhagwat (2007) serta Chu, Wang \& Dai (2009), dimana perspektif pelanggan adalah paling dipentingkan. Posisi kedua perspektif yang memiliki kontribusi tertinggi adalah perspektif keuangan dengan bobot prioritas 0,210, kemudian perspektif pertumbuhan dan pembelajaran 0,147 dan yang terakhir perspektif proses bisnis internal 0,129.

Berdasarkan hasil pembobotan prioritas pada perspektif pelanggan yang dapat dilihat pada 
Gambar 2, peningkatan kepuasan dan kepercayaan pelanggan menjadi sasaran strategik pada prioritas utama. Inisiatif strategik yang dapat dilakukan adalah tanggap melakukan penanganan langsung terhadap keluhan pelanggan, telusuri dengan seksama penyebab keluhan sebelum dilakukan tindakan perbaikan, melakukan quality control (QC) dengan lebih baik dalam penerimaan bahan baku dan produk hasil olahan, serta penuhi order dari kosumen dan berorientasi pada customer driven. Bobot prioritas sasaran strategik pada perspektif pelanggan terkait peningkatan hubungan yang baik dengan pelanggan, peningkatan pesanan yang dipenuhi, peningkatan citra dan performa perusahaan dan terakhir adalah menjadi pemain dominan pada industri fresh cut.

Berdasarkan hasil pembobotan prioritas pada perspektif keuangan yang dapat dilihat pada Gambar 3, mampu memenuhi kewajiban terhadap pemasok menjadi sasaran strategik pada prioritas utama. Inisiatif strategik dapat dilakukan dengan membayar kewajiban secara rutin menurut kontrak perjanjian antara PT Sayuran Siap Saji dan pemasok, monitoring penagihan piutang, sehingga cashflow berjalan dengan baik, maka dipastikan tidak ada dana masuk yang terhambat, sehingga dapat memenuhi kewajiban pada pemasok dengan tepat waktu. Untuk itu PT Sayuran Siap Saji perlu memaksimalkan penggunaaan dana sendiri dan pendapatan untuk meminimalisasi hutang perusahaan. Bobot prioritas selanjutnya peningkatan laba, pengendalian risiko dan terakhir adalah meminimalkan struktur biaya.

Hasil pembobotan prioritas pada perspektif pertumbuhan dan pembelajaran dapat dilihat pada Gambar 4, menunjukkan peningkatan kapabilitas dan pengembangan SDM menjadi sasaran strategik utama. Inisiatif strategik yang dapat dilakukan adalah melakukan perencanaan pelak-sanaan pelatihan setiap divisi dan melakukan pelatihan terhadap pegawai serta menganggarkan biaya khusus untuk pelatihan, juga tetap menjadwalkan pertemuan rutin setiap periodenya. Bobot prioritas sasaran strategik selanjutnya adalah penghargaan pada SDM, peningkatan komitmen karyawan, peningkatan inovasi dan pembelajaran dan terakhir adalah kualitas teknologi informasi yang digunakan.

Hasil pembobotan prioritas pada perspektif proses bisnis internal dapat dilihat pada Gambar 5, yaitu produk dan proses produksi sesuai standar menjadi sasaran strategik pada prioritas utama. Inisiatif strategik yang dapat dilakukan adalah PT Sayuran Siap Saji melakukan monitoring bahan baku yang diterima, produk dalam proses pengolahan sampai pada produk akhir dan penyimpanan, serta menerapkan prinsip HACCP

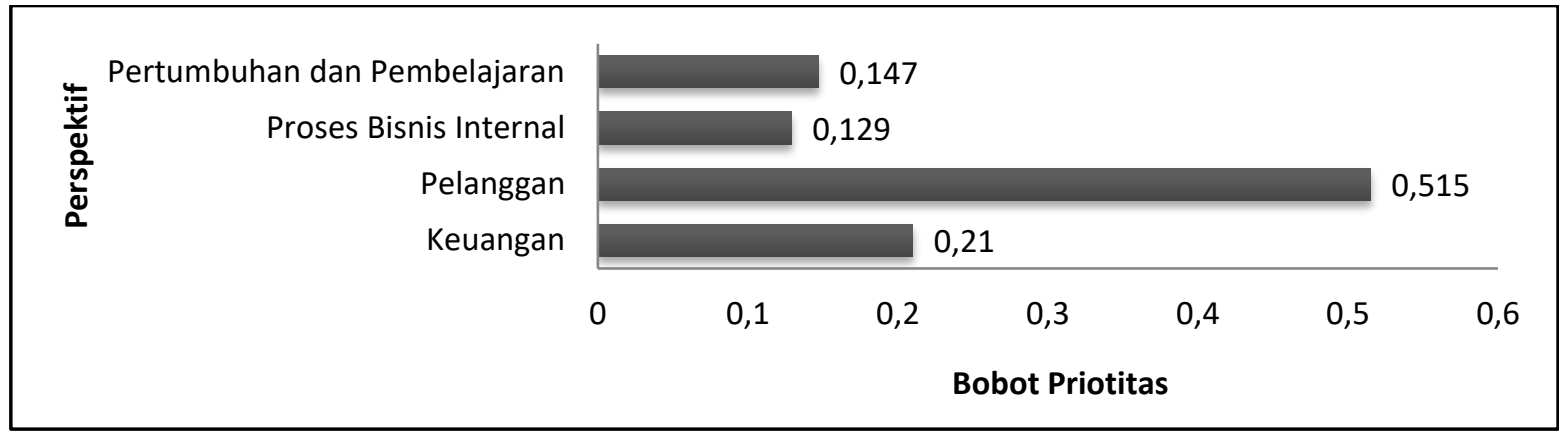

Gambar 1. Bobot prioritas perspektif BSC

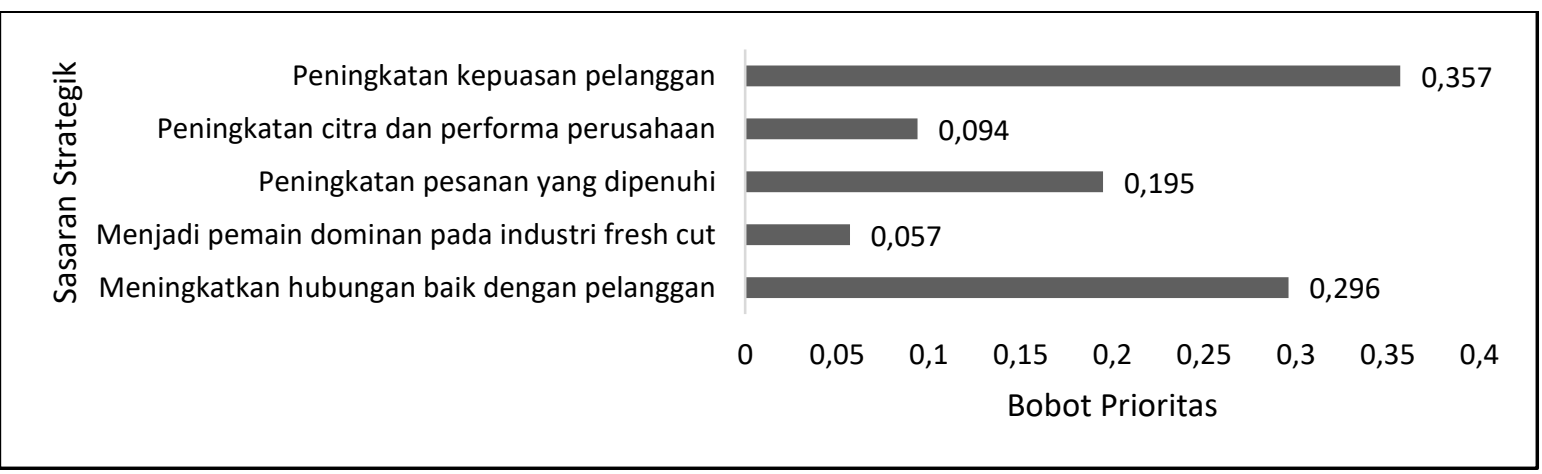

Gambar 2. Bobot prioritas pada perspektif pelanggan 
dalam setiap lingkup pekerjaan. Bobot prioritas sasaran strategik selanjutnya adalah distribusi yang efisien, hubungan dengan pemasok, pelaporan terintegrasi dan tepat waktu dan terakhir adalah peningkatan kerjasama penelitian.

Penerapan BSC sebagai alat pengukuran kinerja harus ditunjang oleh komitmen yang kuat dari manajemen dan sosialisasi kepada seluruh karyawan. Hal ini sejalan dengan penelitian Soleh (2014) yang menyatakan komitmen dan kerjasama antar anggota perusahaan adalah sangat penting dalam penerapan BSC.

\section{Peta Strategi PT Sayuran Siap Saji}

Peta strategi memudahkan organisasi untuk mengkomunikasikan keseluruhan strateginya kepada seluruh anggota dalam rangka pemhaman demi suksesnya pencapaian tujuan organisasi. Dalam peta strategi diuraikan hasil-hasil identi- fikasi sasaran strategi organisasi pada setiap perspektif keuangan, pelanggan, proses bisnis internal, serta pertumbuhan dan pembelajaran. Peta strategi disusun secara kualitatif berdasarkan hasil wawancara mendalam dan diskusi dengan pimpinan PT Sayuran Siap Saji berdasarkan hasil penentuan sasaran strategik perusahaan yang saling terkait. Penyusunan peta strategi secara kualitatif ini sejalan dengan penelitian Subekty (2011). Peta strategi PT Sayuran Siap Saji dapat dilihat pada Gambar 6.

Peta strategi memperlihatkan sasaran strategik dari perspektif keuangan sebagai tujuan akhir, ukuran-ukuran strategik dari keempat perspektif saling berkaitan dan diwakilkan dengan garis dan panah. Peta strategi secara nyata menunjukkan hubungan visi, misi dan strategi perusahaan, serta berbagai sasaran strategik dan tolak ukur dalam setiap perspektif BSC.

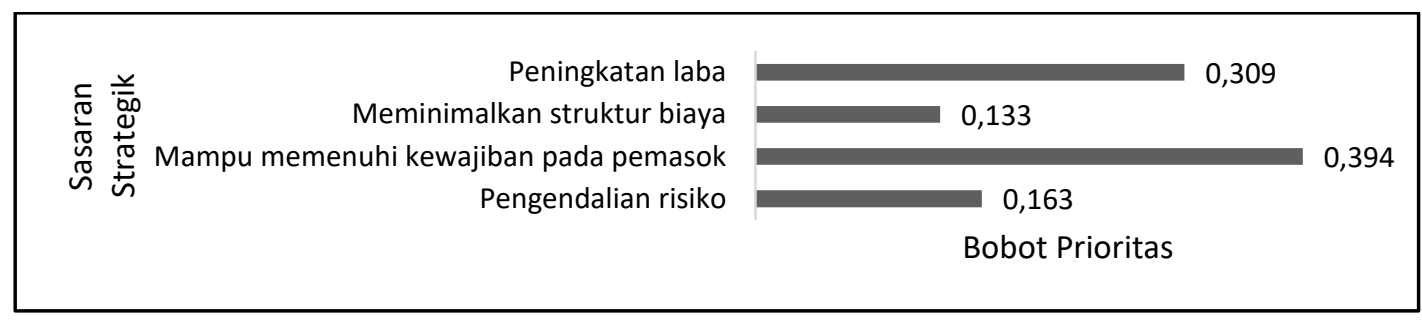

Gambar 3. Bobot Prioritas pada perspektif keuangan

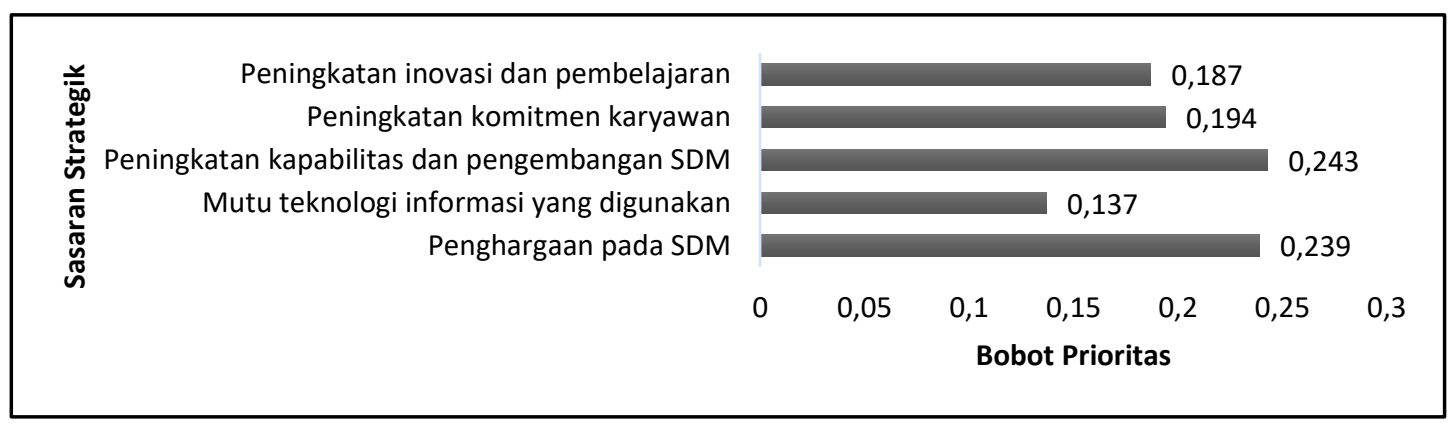

Gambar 4. Bobot prioritas pada perspektif pertumbuhan dan pembelajaran

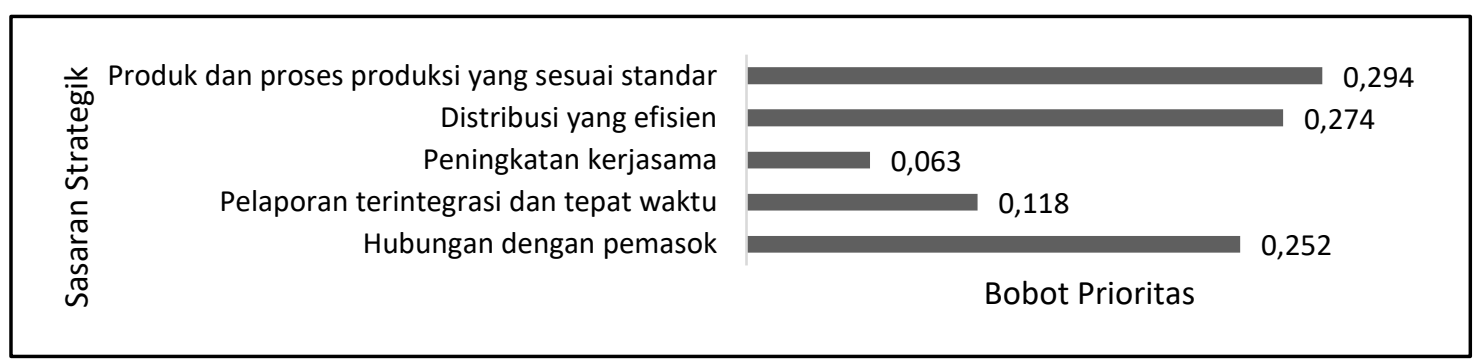

Gambar 5. Bobot prioritas pada perspektif proses bisnis internal 
Visi: Menjadi salah satu leader dalam bidang agribisnis, serta produksi sayur Fresh Cut dengan menerapkan teknologi yang tepat guna untuk meningkatkan peranserta dan kesejahteraan masyarakat petani dalam membangun negara Indonesia

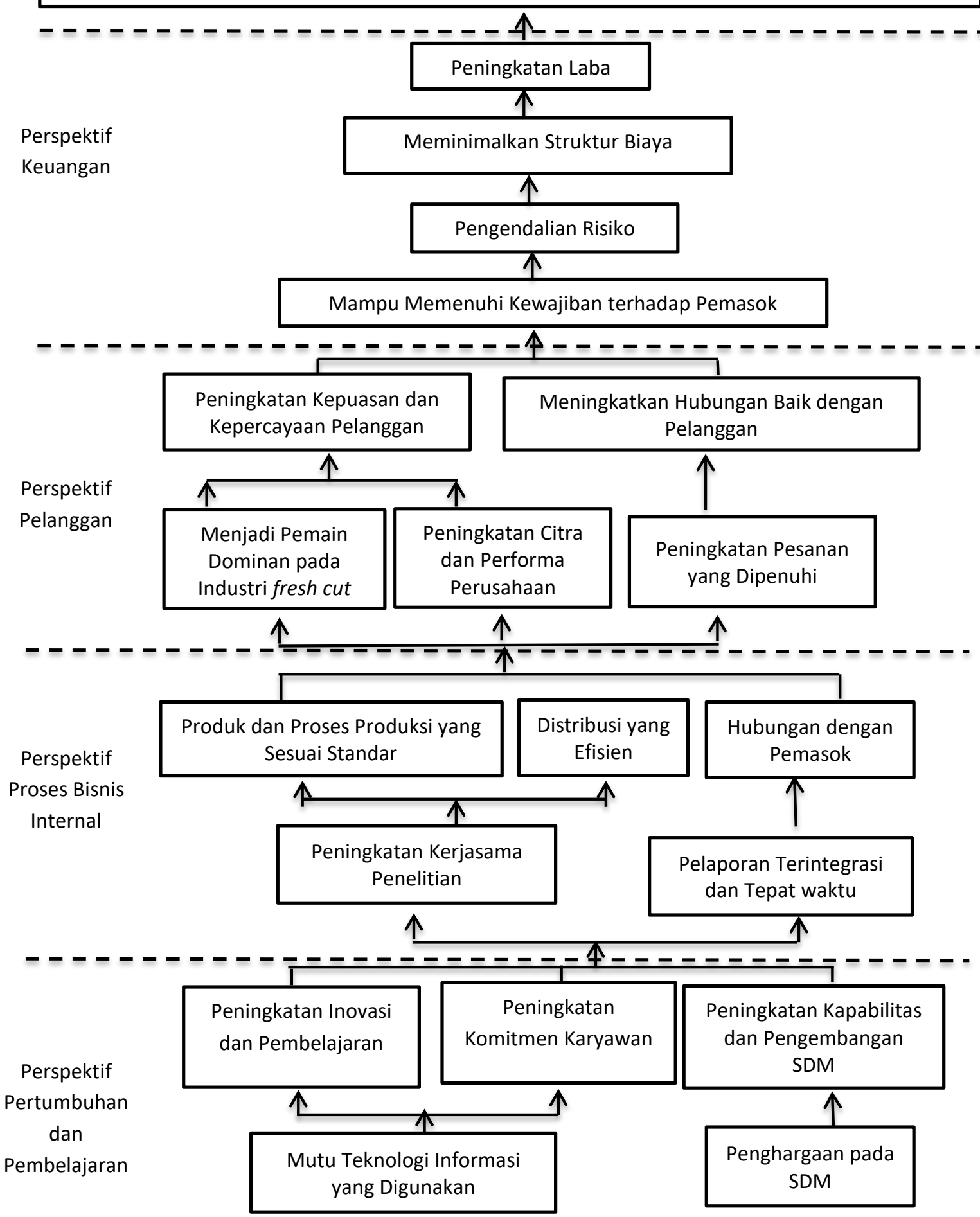

Gambar 6. Peta strategi PT Sayuran Siap Saji

\section{KESIMPULAN}

Berdasarkan hasil perancangan BSC di PT Sayuran Siap Saji dapat disimpulkan hal berikut:

1. Jumlah sasaran strategi yang disusun berdasarkan konsep BSC PT Sayuran Siap Saji adalah 19 sasaran strategik dengan 46 KPI.
2. Penetapan target dan inisiatif strategik dilakukan berdasarkan diskusi mendalam dengan pihak manajemen dan beberapa indikator tersebut terdapat pada RKAP PT Sayuran Siap Saji.

3. Penentuan prioritas sasaran strategik dilakukan dengan metode AHP yang pengolahannya 
dilakukan dengan software expert choice 2000, perspektif pelanggan berada pada prioritas tertinggi, kemudian perspektif keuangan, perpektif pertumbuhan dan pembelajaran dan terakhir perspektif proses bisnis internal.

4. Peta strategi PT Sayuran Siap Saji memperlihatkan keterkaitan antara sasaran strategik dari setiap perspektif, dimana semua ukuran strategik perspektif berhubungan erat dengan kinerja dari perspektif keuangan.

\section{DAFTAR PUSTAKA}

Callado, A.A.C., L. Jack. 2015. Reflective practice balanced scorecard metrics and specific supply chain roles. International Journal of Productivity and Performance Management. 64(2): 288-300. doi: 10.1108/IJPPM-05-20140071.

Ching, Y., L. Chan. 2006. An analytic hierarchy framework for evaluating Balanced Scorecards of healthcare organizations. Canadian Journal of Administrative Sciences. 23(2): 85104. doi:10.1111/j.1936-4490.2006.tb00683.x.

Chu, H.L., C.C. Wang, Y.T. Dai. 2009. A study of a Nursing Department performance measurement system: using the balanced scorecard and the analytic hierarcy process. Nursing Economic. 27(6): 401-407.

Erbasi, A., R. Parlakkaya. 2012. The use of analytic hierarchy process in the balanced scorecard: an approach in a Hotel Firm. Business and Management Review. 2(2): 23-37.

Fakharian, A., A. Danaei, H. Hematian. 2014. Evaluation of Hadid Firm's performance using the Balanced Scorecard (BSC) model. Kuwait Chapter of Arabian Journal of Business and Management Review. 3(6a): 42-64. doi:10.12816/0018201

Hanuma, S., E. Kiswara. 2011. Analisis balanced scorecard sebagai alat pengukur kinerja perusahaan (Studi kasus pada PT Astra Honda Motor) [tesis]. Semarang (ID): Universitas Diponegoro.

Hidayati, J. 2012. Penerapan Analytical Network Process (ANP) pada sistem pengukuran kinerja di Kebun Sidamanik Pematang Siantar. Jurnal Departemen Teknik Industri Fakultas Teknik. 7(1): 51-60. doi:10.12777/ jati.7.1.51-60.

Johnson, C. 2007. Introduction to balanced scorecard and performance measurement systems. Balanced Scorecard for State-
Owned Enterprises [Internet]. [diunduh 2016 Mar 12]. Tersedia pada: http//www.adb.org/Documents/Books/Bala nced Scorecard/Chap1.pdf:1-13.

Jovanovic, J., Z. Krivokapic. 2008. AHP in implementation of balanced scorecard. International Journal for Quality research. 2(1): 59-67. doi: UDK - 519.816 S.

Kaplan, R., D. Norton. 1996. Translating Strategic into Action -The Balanced Scorecard. Boston (US): Harvard Business School Press.

Lokatili, T.A., Devie. 2013. Analisa pengaruh penggunaan balanced scorecard terhadap keunggulan bersaing dan kinerja perusahaan. Business Accounting Review. 1(2): 72:81.

Marimin, N. Maghfiroh. 2010. Aplikasi Teknik Pengambilan Keputusan dalam Manajemen Rantai Pasok. Bogor (ID): IPB Press

Meena, K., J. Thakkar. 2014. Development of balanced scorecard for healthcare using interpretive structural modeling and analytic network process. Journal of Advances in Management Research. 11(3): 232-256. doi:http://dx.doi.org/10.1108/JAMR-122012-0051

Paustian, M., M. Wellner, L. Theuvsen. 2015. The balanced scorecard as a management tool for arable Farming. Journal of Food System Dynamic. 6(3): 147-158. doi: 10.18461.

Pietrzak, M., J. Paliszkiewicz, B. Klepacki. 2015. The application of the balanced scorecard (BSC) in the higher education setting of a polish university. Journal of Applied Knowledge Management. 3(1): 151-164.

Rauf, A.R. 2012. Perancangan sistem manajemen kinerja berbasis balanced scorecard di Unit Manufaktur Keju Kraft Foods Indonesia [tesis]. Bogor (ID): IPB.

Rosmiati, M, I. Widiyanto. 2015. Sistem informasi pengukuran kinerja pada perke-bunan kelapa sawit dengan menggunakan metode balanced scorecard. Jurnal Sistem Informasi Bisnis. 5(1): 1-8. doi:10.21456/ vol5iss1pp1-8.

Saaty, T.L.. 2001. Decision Making for Leaders-The Analytic Hierarchy Process for Decisions in a Complex World. Pittsburgh (US): RWS Publications.

Sharma, M.K., R. Bhagwat. 2007. An integrated BSC-AHP approach for supply chain management evaluation. Measuring Business Excellence Journal. 11(3): 57-68. doi: 10.1108/13683040710820755. 
Soleh, C.M. 2014. Perancangan sistem pengukuran kinerja perusahaan dengan menggunakan metode balanced scorecard Studi kasus di perusahaan jasa pengangkutan batubara PT TPM [tesis] Bogor (ID): IPB.

Subekty. 2011. Perancangan balanced scorecard induk Koperasi ABC [tesis]. Jakarta (ID): Universitas Indonesia.

Suhendi. 2012. Perancangan pengukuran kinerja perguruan tinggi dengan metode balanced scorecard dan analytic network process (ANP) [tesis]. Bogor (ID): MB IPB.

Sumarwan, U., A. Djunaidi, Aviliani, H.C.R. Singgih, J.A. Sayono, R.R Budidarmo, S. Rambe. 2009. Pemasaran Strategik Strategi untuk Pertumbuhan Perusahaan dalam Penciptaan Nilai bagi Pemegang Saham. Aulia N, Rusniati E, editor. Bogor (ID): Inti Prima Promosindo.
Suryani, D., R. Syarief, A.I. Suroso. 2014. Perancangan balanced scorecard untuk pengembangan strategi di Seameo Biotrop. Jurnal Manajemen \& Agribisnis. 11(1): 33-40. doi: http://dx.doi.org/10.17358/jma.11.1.3340.

Suswono. 2012. Strategi peningkatan daya saing organisasi: Logistik pangan nasional yang berkelanjutan: Studi kasus Bulog [disertasi]. Bogor (ID): IPB.

Wang, L., H. Zhang, Y.R. Zeng. 2012. Fuzzy Analytic Hierarchy Process (FAHP) and balanced scorecard approach for evaluating performance of Third-Party Logistics (TPL) enterprises in chinese context. African Journal of Business Management. 6(2): 521-529. doi:10.5897/AJBM11.1520

Wang, W.C. 2012. A study of HR Consulting Firms' performance measurement indicators by using Balanced Scorecard-Analysis of Fuzzy AHP. Journal of Accounting, Finance \& Management Strategy. 7(2): 93-114. 